Jurnal Kajian Bimbingan dan Konseling

Vol 1, No. 1, 2016, hlm. 19-26

Tersedia Online di http://journal.um.ac.id/index.php/bk

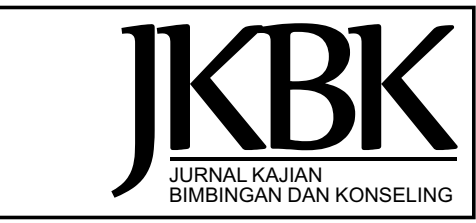

\title{
EFEKTIFITAS PENGGUNAAN MEDIA FILM UNTUK MENINGKATKAN EMPATI SISWA KELAS VII SMP
}

\author{
Alan Auliyah, Elia Flurentin \\ Bimbingan dan Konseling-Fakultas Ilmu Pendidikan-Universitas Negeri Malang-Jl. Semarang No. 5 Malang \\ E-mail:alan_auliyah@yahoo.co.id
}

\begin{abstract}
This study aims to determine the effectiveness of the use of film to improving emphaty sevents grade students junior high school. The study design used a quasi-experimental design using the design of one group pretest-posttest design. Subjects in this study were six students who have the lowest levels of emphaty in the classroom. The research instrument used is the scale of emphaty and guidance experiment. The hypothesis testing is using the Wilcoxon test. Wilcoxon test results showed that the difference value $(\mathrm{z})$ is- 2.201 with a significance value of 0.028 . Significance value less than 0.05 , which means that Ho is rejected, so it can be concluded that the use of film is effective to improving emphaty among sevents grade student of junior high school.
\end{abstract}

Key words: movies; empathy; sevents grade junior high school

\begin{abstract}
Abstrak: Penelitian ini bertujuan untuk mengetahui keefektifan penggunaan media film untuk meningkatkan empati siswa kelas VII SMP. Desain penelitian menggunakan desain eksperimen semu dengan menggunakan rancangan one group pretest-posttest design. Subjek dalam penelitian ini adalah enam siswa yang mempunyai tingkat empati terendah dalam satu kelas. Instrumen penelitian yang digunakan adalah skala empati dan pedoman eksperimen.Uji hipotesis dalam penelitian ini menggunakan uji Wilcoxon. Hasil uji Wilcoxon menunjukkan bahwa nilai beda (z) adalah -2,201 dengan nilai signifikansi 0,028. Nilai signifikansi lebih kecil dari 0,05 yang artinya Ho ditolak, sehingga dapat disimpulkan bahwa penggunaan media film efektif untuk meningkatkan empati siswa kelas VII SMP.
\end{abstract}

Kata Kunci: media film; empati; siswa kelas VII SMP

Masa remaja merupakan periode transisi antara masa kanak-kanak dan masa dewasa. Menurut WHO (dalam Sarwono, 2011) definisi remaja adalah individu yang mengalami perkembangan psikologis dan pola identifikasi dari kanak-kanak menjadi dewasa. Para remaja kebanyakan masih sangat labil dan masih dalam taraf pencarian identitas atau jati diri, sehingga kebanyakan remaja masih sangat labil dan mudah terpengaruh oleh hal-hal baru. Salah satu hal yang dapat berdampak buruk bagi perkembangan seorang remaja adalah perkembangan kemajuan teknologi yang sangat cepat.

Durkheim (dalam Sarwono, 2011) berpendapat bahwa kemajuan teknologi yang canggih sudah membuat remaja menjadi lebih individualis yang menyebabkan remaja bertindak hanya menurut kepentingannya sendiri. Selain membuat individu semakin individualis, kemajuan teknologi juga membuat berkurangnya rasa kepedulian sosial dikalangan remaja. Dengan berkurangnya rasa kepedulian remaja itu bisa berdampak buruk pada 
kehidupan sosial para remaja. Dilihat dari keadaan ini, sudah selayaknya mereka mendapatkan perhatian lebih, terutama di dalam bidang pendidikan formal.

Kartono (2003) menyatakan perilaku prososial adalah suatu tindakan yang didalamnya terdapat unsurunsur kebersamaan, kerjasama, kooperatif, dan altruisme. Indikasi perilaku sosial yang baik adalah seperti sopan santun, saling tolong-menolong, suka bekerjasama, menghormati orang tua, melestarikan lingkungan, tidak memaksakan kehendak kepada orang lain. Byrne \& Baron (2003) menyatakan bahwa ada dua faktor yang mempengaruhi perilaku prososial. Pertama adalah faktor situasional yang meliputi: (1) daya tarik, (2) atribusi, dan (3) model-model prososial. Faktor yang kedua adalah faktor personal yang meliputi (1) keadaan emosional, dan (2) empati,

Berdasarkan pengamatan peneliti pada saat melaksanakan Praktikum Bimbingan Konseling (PBK), banyak dijumpai para pelajar yang menunjukkan sikap yang kurang pro-sosial. Misalnya siswa kelas IX merasa lebih berkuasa dan bisa menyuruh adik tingkatnya. Peneliti juga menjumpai siswi kelas IX yang berkelahi dengan siswi kelas VII hanya karena dia jengkel adik kelasnya itu melihat kearahnya. Selain itu, juga masih ada siswa yang membuat kelompok-kelompok tertentu dalam satu kelas, ada juga beberapa siswa yang dikucilkan di dalam kelas. Salah satu faktor penyebab kasus-kasus seperti itu adalah tingkat empati individu yang rendah. Hal ini selaras dengan pendapat Byrne \& Baron (2003) yang menyatakan bahwa empati merupakan kemampuan individu untuk dapat merasakan perasaan atau pengalaman orang lain. Oleh karena itu, dengan mempunyai sikap empati seorang individu dapat berbagi perasaan dengan orang lain dalam suasana suka maupun duka, kesediaan memberikan bantuan kepada orang lain baik materiil maupun moril dan juga kesediaan untuk bekerjasama dengan orang lain demi tercapainya suatu tujuan.

Menurut Eisenberg (dalam Taufik, 2012) dalam proses berempati, individu melibatkan aspek afektif dan kognitif. Aspek afektif merupakan kecenderungan seseorang untuk mengalami perasaan emosional orang lain yaitu ikut merasakan ketika orang lain merasa sedih, menangis, terluka, menderita bahkan disakiti sedangkan aspek kognitif dalam empati difokuskan pada proses intelektual untuk memahami perspektif orang lain dengan tepat dan menerima pandangan mereka, misalnya membayangkan perasaan orang lain ketika marah, kecewa, senang, memahami keadaan orang lain dari cara berbicara, dari raut wajah dan cara pandang dalam berpendapat.

Dalam hal ini bimbingan dan konseling (BK) mempunyai peran yang sangat penting untuk mengembalikan rasa peka terhadap sesama. Menurut Hamrin dan Clifford (dalam Prayitno, 2008) tujuan BK di sekolah adalah untuk membantu individu membuat pilihan-pilihan dan penyesuaian-penyesuaian dalam hubungannya dengan situasi-situasi tertentu. Salah satu media BK yang mampu memfasilitasi siswa untuk mengembalikan rasa empatinya adalah media film. Alasan peneliti memilih menggunakan media film adalah karena film mempunyai dampak emosional yang besar/tinggi, film sangat cocok mengajarkan masalah-masalah yang menyangkut domain kognitif maupun afektif. Arsyad, A. (2011), menyatakan bahwa dalam proses pembelajaran, film mempunyai fungsi yang terkait dengan dua hal, yaitu untuk tujuan kognitif dan afektif. Film dapat digunakan dalam BK sama seperti cerita maupun media-media BK yang lain. Hal ini karena film dapat meningkatkan kemungkinan konseli dapat menemukan ide dan pikiran baru. Dari segi kognitif, film mampu membantu individu dalam mempelajari manfaat atau inspirasi yang ada di dalam film. Film mampu mengajarkan sesuatu yang belum pernah dilakukan secara langsung. Dari segi afektif, film dapat mempengaruhi emosi dan sikap. Hal ini membuat individu tersebut mendapatkan semangat dan motivasi untuk meniru apa yang ada dalam film. Sikap individu maupun kelompok dapat dipengaruhi bahkan diubah dengan menggunakan film yang telah dirancang untuk hal tersebut.

Berdasarkan permasalahan di atas, maka media film dianggap mampu untuk meningkatkan empati sosial remaja karena film merupakan salah satu media bimbingan yang mampu menginspirasi siswa yang pada akhirnya mampu meningkatkan empati sosial remaja. Atas dasar pemikiran tersebut maka tujuan dari penelitian ini adalah untuk meningkatkan empati siswa kelas VII SMP. 


\section{METODE}

Penelitian ini merupakan penelitian eksperimen dengan pendekatan kuantitatif. Rancangan penelitian yang digunakan dalam penelitian ini adalah One Group Pretest-Posttest Design. Dalam desain ini, efek suatu perlakuan terhadap variabel akan diuji dengan cara membandingkan keadaan variabel pada kelompok eksperimen sebelum dan setelah diberikan perlakuan. Penelitian ini dilaksanakan di SMP Negeri 6 Malang dan subjek penelitian ini sebanyak enam siswa yang mempunyai tingkat empati terendah dalam satu kelas. Penelitian ini menggunakan satu kelompok eksperimen tanpa menggunakan kelompok kontrol. Instrumen penelitian yang digunakan adalah skala empati dan pedoman eksperimen.

Ada tiga tahapan dalam eksperimen ini. Tahap pertama adalah melakukan pretest. Dalam pretest, siswa diminta mengisi skala empati. Pretest ini bertujuan untuk mengetahui tingkat empati siswa sebelum diberikan perlakuan (treatment). Tahap kedua adalah treatment, yang diberikan dalam bentuk pemberian film pendek yang mempunyai nilai-nilai yang dapat memotivasi siswa untuk meningkatkan rasa empatinya. Treatment dilaksanakan sebanyak tujuh kali pertemuan dan setiap pertemuan diberikan satu tayangan film, setelah film selesai ditayangkan siswa diminta untuk merefleksikan nilai-nilai yang terkandung di dalam film tersebut. Tahap ketiga adalah posttest. Pada saat posttest siswa juga diminta untuk mengisi skala empati yang sama pada saat pretest. Posttest ini bertujuan untuk mengetahui peningkatan empati siswa setelah diberikannya perlakuan (treatment). Metode non parametrik yang digunakan dalam penelitian ini menggunakan uji Wilcoxon yang merupakan uji non-parametrik dengan tidak mensyaratkan distribusi data normal yang digunakan untuk mengetahui keefektifan penggunaan media film untuk meningkatkan empati siswa kelas VII SMP.

\section{HASIL}

Setelah dilakukan pengumpulan data, maka langkah selanjutnya adalah penyajian data hasil penelitian. Data yang akan disajikan adalah sebagai berikut:

\section{Penyajian Data Hasil Pretest.}

Pemberian pretest berupa skala empati yang dijabarkan dalam empat indikator yang kemudian dideskripsikan menjadi 29 butir pernyataan. Skala empati ini diberikan kepada 31 orang siswa kelas VII SMP Negeri 6 Malang. Jabaran hasil skala empati dapat dilihat pada tabel 1.

Dari tabel 1, dapat diketahui bahwa terdapat dua orang siswa yang masuk dalam kategori rendah, dua belas orang siswa yang masuk dalam kategori sedang dan tujuh belas orang siswa berkategori tinggi. Subjek penelitian dalam penelitian ini sebanyak enam orang siswa yang dipilih berdasarkan hasil skor pretest terendah dalam satu kelas. Jabaran hasil analisis skala empati (pretest) dapat dilihat pada tabel 2.

\section{Treatment}

Pelaksanaan treatment dilakukan dalam tujuh kali pertemuan yang dilaksanakan mulai tanggal 9 Mei 2015 sampai tanggal 23 Mei 2015. Berikut jabaran kegiatan yang dilakukan pada setiap pertemuan.

Pertemuan pertama dilakukan pada tanggal 9 Mei 2015. Pertemuan kali ini dilaksanakan di dalam ruang kelas dan berlangsung selama 45 menit. Peneliti mengawali pertemuan pertama dengan mengucap salam dan membangun rapport. Untuk membina hubungan baik dengan siswa, peneliti memberikan kegiatan ice breaking yang berupa “Tulis Cerita Berputar”. Setelah melakukan ice breaking, diberikan materi awal seputar empati agar siswa mempunyai pengetahuan awal tentang apa yang dimaksud dengan empati. Selanjutnya, diberikan pretest dengan cara meminta siswa mengisi lembar skala empati. Setelah semua siswa selesai mengisi lembar skala empati, kemudian siswa diminta membuat komitmen agar dapat bertanggung jawab dalam mengikuti treatment yang diberikan sampai selesai sesuai dengan jadwal. Selain itu, siswa juga diberikan gambaran mengenai kegiatan yang akan dilakukan. Peneliti juga memberikan kesempatan kepada siswa untuk bertanya tentang hal-hal yang belum jelas, sehingga siswa dapat mengikuti setiap pertemuan dalam 
Tabel 1. Rekapitulasi Data Empati Siswa Kelas VII

\begin{tabular}{lrrr}
\hline \multicolumn{1}{c}{ Kategori } & Rentangan skor & Frekuensi \\
\hline Tinggi & & $89-116$ & 17 \\
Sedang & $59-88$ & 12 \\
Rendah & & $29-58$ & 2 \\
& Total & & 31 \\
\hline
\end{tabular}

Tabel 2. Hasil Pretest Tingkat Empati Subjek Penelitian

\begin{tabular}{lrc}
\hline \multicolumn{1}{c}{ Subjek } & Skor & Kategori tingkat empati siswa \\
\hline RA & 72 & Sedang \\
T & 64 & Sedang \\
PD & 62 & Sedang \\
AR & 61 & Sedang \\
SAZ & 58 & Rendah \\
FI & 53 & Rendah \\
\hline
\end{tabular}

kegiatan eksperimen dengan jelas. Setelah dirasa siswa sudah paham mengenai setiap kegiatan yang akan dilakukan, pertemuan diakhiri dengan penyampaian rencana kegiatan yang akan dilakukan pada pertemuan selanjutnya.

Pertemuan kedua dilaksanakan pada 11 Mei 2015 di dalam ruang kelas. Pertemuan diawali dengan mengucap salam dan membangun rapport, kemudian dilanjutkan dengan menjelaskan tujuan kegiatan pada pertemuan hari itu dan menanyakan kesiapan subjek penelitian untuk melaksanakan kegiatan pada hari itu. Sebelum penayangan film, peneliti terlebih dahulu membacakan sinopsis singkat film. Film yang diputarkan pada pertemuan hari ini adalah "Surat Kecil untuk Tuhan”. Film ini menceritakan Gita Sesa Wanda Cantika atau yang lebih dikenal dengan nama panggilan Keke. Keke mengidap Rhabdomyosarcoma (Kanker Jaringan Lunak), akibatnya, semua rambut Keke sedikit demi sedikit mulai rontok, kulitnya mengering, dan sering mual-mual. Meskipun dengan kondisi seperti itu, Keke masih beruntung karena mempunyai enam sahabat karib yang selalu setia menemaninya dan seorang kekasih yang juga begitu menyayanginya, yaitu Andy.

Pertemuan ketiga dilaksanakan pada 13 Mei 2015 di dalam ruang kelas. Kegiatan diawali dengan mengucap salam dan membangun rapport, menjelaskan tujuan kegiatan pada pertemuan hari ini dan selanjutnya peneliti membacakan sinopsis singkat tentang film yang akan ditayangkan. Film yang diputarkan pada pertemuan ketiga adalah "Negeri 5 Menara". Setelah menonton film, subjek penelitian diminta untuk mengisi lembar refleksi isi dan refleksi pengalaman.

Pertemuan keempat dilaksanakan pada 15 Mei 2015 dan dilaksanakan di dalam ruang kelas. Pada pertemuan keempat, peneliti menayangkan film “Ayah Mengapa Aku Berbeda”, yang menceritakan seorang gadis tuna rungu yang mempunyai impian untuk membahagiakan sang ayah. Sebagian siswa mengaku pernah menonton film tersebut. Mereka mengaku terharu ketika menonton film tersebut. Hal ini dibuktikan dengan antusiasnya subjek penelitian yang aktif dalam diskusi refleksi. Pada saat uji komitmen, hampir sebagian besar subjek penelitian berpendapat bahwa usaha keras yang disertai kesungguhan akan menghasilkan kesuksesan.

Pertemuan kelima dilaksanakan pada 18 Mei 2015 di dalam ruang kelas. Film yang ditayangkan pada pertemuan kelima adalah “Sang Pemimpi”. Film ini menceritakan tentang perjuangan tiga orang anak untuk meraih mimpi dan cita-citanya. Hampir semua semua mengaku pernah menonton film tersebut. Walaupun mereka mengaku penah menonton film tersebut, subjek penelitian tetap antusias untuk menonton film tersebut. Hal itu dikarenakan mereka tertarik dengan bagaimana usaha dan perjuangan ketiga tokoh dalam menggapai impian dan cita-citanya.

Pertemuan keenam dilaksanakan pada 20 Mei 2015 di dalam ruang kelas. Film yang ditayangkan pada pertemuan keenam adalah "Denias". Film ini menceritakan tentang kehidupan anak-anak di daerah Papua. Di film ini ada dua tokoh utama yang saling bertolak belakang. Pertama ada tokoh Denias, yang digambarkan sebagai anak masyarakat biasa namun mempunyai sikap pantang menyerah dalam belajar. Tokoh kedua 
Tabel 3. Hasil Posttest Tingkat Empati Subjek Penelitian

\begin{tabular}{crc}
\hline Subjek & \multicolumn{1}{c}{ Skor } & Kategori tingkat empati siswa \\
\hline AR & 91 & Tinggi \\
SAZ & 81 & Sedang \\
RA & 94 & Tinggi \\
PD & 93 & Tinggi \\
T & 99 & Tinggi \\
FI & 101 & Tinggi \\
\hline
\end{tabular}

adalah Noel yang digambarkan sebagai anak ketua suku dan mempunyai sikap yang angkuh dan Noel sangat membenci Denias. Sebagian subjek penelitian mengatakan bahwa mereka belum pernah menonton film ini, sehingga mereka sangat antusias saat melakukan kegiatan refleksi. Hal ini dapat dilihat dari hampir semua subjek penelitian yang ikut berpartisipasi dalam mengungkapkan pendapatnya. Peneliti menguji komitmen yang dibuat dengan menanyakan kembali kepada subjek penelitian. Subjek penelitian berpendapat bahwa kita tidak boleh sekalipun meremehkan orang lain karena belum tentu kita itu lebih baik daripada orang yang kita remehkan. Setelah menguji komitmen subjek penelitian, peneliti menyimpulkan kegiatan yang telah dilakukan dan menyampaikan kegiatan yang akan dilakukan pada pertemuan selanjutnya. Peneliti menjelaskan bahwa pada pertemuan selanjutnya akan dilaksanakan posttest yang bertujuan untuk mengukur sikap empati subjek penelitian setelah diberi treatment.

Pertemuan ketujuh dilaksanakan pada 23 Mei 2015 di dalam ruang kelas. Pertemuan ketujuh diisi dengan kegiatan kesimpulan dari lima film yang telah ditayangkan. Kegiatan dilakukan dengan cara diskusi dan tanya jawab dengan subjek penelitian mengenai film-film yang telah ditayangkan. Setelah kegiatan kesimpulan selesai, peneliti kemudian memberikan lembar skala empati kepada subjek penelitian. Setelah semua subjek penelitian selesai mengisi lembar skala empati, kegiatan dilanjutkan dengan pengakhiran. Peneliti mengakhiri pertemuan pada hari itu dan berterima kasih telah mengikuti semua kegiatan yang telah ditentukan dengan baik.

\section{Penyajian Data Hasil Posttest}

Kegiatan posttest dilakukan pada akhir pertemuan untuk mengetahui tingkat empati subjek penelitian setelah diberikan treatment. Hasil posttest subjek penelitian setelah diberikan treatment dapat dilihat pada Tabel 3. Dari Tabel 3 dapat dilihat bahwa semua subjek penelitian mengalami peningkatan tingkat empati. Berikut juga dijelaskan deskripsi tingkat perubahan setiap subjek penelitian.

Hasil treatment Subjek AR mengalami peningkatan sebanyak 30 poin. Pada saat pretest, subjek mendapatkan skor 61 dan pada saat posttest mendapatkan skor 91. Dari hasil observasi setiap pertemuan, subjek tampak cukup serius dan sungguh-sungguh, baik itu pada saat penayangan maupun saat refleksi. Pada saat menonton film, subjek juga sambil berdiskusi dengan teman sebelahnya. Pada saat refleksi pun subjek terlihat selalu aktif pada setiap pertemuan.

Subjek SAZ mengalami peningkatan sebanyak 23. Pada saat pretest, subjek mendapatkan skor 58 dan pada saat posttest mendapatkan skor 81. Dari hasil observasi setiap pertemuan, subjek cukup serius saat menonton penayangan film. Meskipun terkadang sambil melihat film, subjek terlihat mengobrol dengan teman sebelahnya. Pada saat refleksi, subjek cukup aktif meskipun pada pertemuan keempat subjek kurang aktif.

Subjek RA mengalami peningkatan sikap empati, yang awalnya berkategori sedang, naik menjadi tinggi. Pada saat pretest, subjek penelitian mendapatkan skor 72 dan pada saat posttest mendapatkan skor 94. Subjek mengalami peningkatan sebanyak 22. Dari hasil observasi pada setiap pertemuan, subjek cukup serius dalam melihat penayangan film, namun pada saat refleksi, subjek kurang begitu aktif dalam mengungkapkan pendapatnya. 
Tabel 4. Data Perbedaan Skor Tingkat Empati Subjek Penelitian

\begin{tabular}{crcrcr}
\hline Subjek & \multicolumn{3}{c}{ Pretest } & & \multicolumn{2}{c}{ Posttest } & \multirow{2}{*}{ Peningkatan } \\
\cline { 2 - 5 } & Skor & Kategori & Skor & Kategori & \\
\hline AR & 61 & Sedang & 91 & Tinggi & 30 \\
SAZ & 58 & Rendah & 81 & Sedang & 23 \\
RA & 72 & Sedang & 94 & Tinggi & 22 \\
PD & 62 & Sedang & 93 & Tinggi & 31 \\
T & 64 & Sedang & 99 & Tinggi & 35 \\
FI & 53 & Rendah & 101 & Tinggi & 48 \\
Rata-rata & 61,67 & & 93,16 & & 31,5 \\
\hline
\end{tabular}

Subjek PD cukup serius dalam mengikuti seluruh kegiatan treatment. Dari hasil refleksi pada setiap pertemuan menunjukkan semakin membaiknya pemahaman subjek akan pentingnya mempunyai sikap empati. Selain dari hasil refleksi, peningkatan empati subjek juga dapat dilihat dari peningkatan skor yang didapat, yakni sebesar 31. Pada saat pretest, subjek mendapatkan skor 62 dan pada saat posttest mendapatkan skor 93.

Dari hasil observasi setiap pertemuan, sejak pertemuan pertama subjek $\mathrm{T}$ sudah terlihat mengikuti seluruh kegiatan dengan serius dan sungguh-sungguh. Hal itu dapat dilihat dari peningkatan yang dialami subjek yakni sebanyak 35. Pada saat pretest, subjek mendapatkan skor 64 dan pada saat posttest mendapatkan skor 99.

Pada saat pretest, subjek FI mendapatkan skor 53 dan pada saat posttest mendapatkan skor 101. Subjek mengalami peningkatan sebanyak 48. Dari hasil observasi setiap pertemuan, subjek menunjukkan sikap yang cukup antusias dalam mengikuti setiap pertemuan. Memang pada pertemuan pertama subjek kurang begitu serius dalam mengikuti treatment, namun karena peneliti memberikan perhatian khusus, akhirnya pada pertemuan selanjutnya subjek lebih serius dan bersungguh-sungguh dalam mengikuti seluruh kegiatan treatment.

Dari penjelasan di atas, terdapat perbedaan hasil penelitian pada saat pretest dengan posttest. Perbedaan hasil penelitian dapat dilihat pada Tabel 4. Dalam tabel 4 dapat dilihat bahwa hasil pretest dari enam orang siswa yang memperlihatkan skor minimum 53 dan skor maksimum 72. Setelah diberikan treatment, hasil posttest menunjukkan skor minimum 81 dan skor maksimum 101. Dari penjabaran tersebut dapat dikatakan bahwa semua subjek penelitian mengalami peningkatan sikap empati. Hal ini disebabkan karena para siswa sudah menyadari pentingnya meningkatkan sikap empati.

\section{PEMBAHASAN}

Sikap empati sangat penting dalam kehidupan sehari-hari. Sikap empati membuat seseorang menjadi tahu bagaimana kondisi psikologis orang lain, sehingga seseorang dapat memahami apa yang sedang dipikirkan dan dirasakan orang lain. Pemahaman ini akan menjadi tali perekat dalam hubungan sosial, dan meningkatkan kualitas hubungan. Empati mempunyai hubungan yang sangat erat dengan perilaku pro-sosial. Goleman (dalam Taufik, 2012) menyebutkan bahwa orang-orang yang rendah sikap empatinya, dapat mengalami hambatan dalam perkembangan, membatasi pergaulan dan melemahkan kualitas hubungan dengan sesama.

Konselor sekolah mempunyai peran yang besar dalam membantu meningkatkan sikap empati siswa. Namun sampai saat ini konselor di sekolah belum memperhatikan pemilihan media apa yang sesuai agar empati siswa dapat meningkat dan dapat tersimpan lama di dalam diri siswa. Media film merupakan salah satu media yang dapat digunakan oleh konselor dalam melaksanakan bimbingan kelompok. Film sangat cocok mengajarkan masalah-masalah yang menyangkut domain kognitif maupun afektif. Dari segi kognitif konseli mendapat inspirasi apa yang harus dilakukan. Dari segi afektif konseli mendapat semangat dan motivasi untuk meniru apa yang ada dalam film. Menurut Nursalim, M., \& Mustaji (2010:20), salah satu keuntungan dari media film adalah memberikan kesan mendalam, yang dapat mempengaruhi sikap siswa.

Penelitian yang dilakukan kepada enam siswa kelas VII SMP ini terdiri dari dua siswa yang mempunyai tingkat empati rendah dan empat siswa yang mempunyai tingkat empati sedang mendekati rendah. Skor 
terendah yang diperoleh subjek penelitian sebelum treatment adalah 53 dan skor tertinggi adalah 72 . Setelah dilakukan treatment, keenam subjek penelitian yang awalnya ada dikategori rendah dan sedang mengalami peningkatan sehingga menjadi ada dikategori sedang dan tinggi. Hal ini menunjukkan bahwa terdapat perbedaan tingkat empati siswa kelas VII SMP sebelum dan sesudah treatment. Penerimaan hipotesis dalam penelitian ini ditunjukkan dari hasil analisis data yang menunjukkan nilai signifikansinya (2-tailed) adalah 0,028. Nilai signifikansinya lebih kecil dari 0,05 (nilai asyimp.sig < 0,05) menunjukkan bahwa $\mathrm{H}_{0}$ ditolak, sehingga dapat disimpulkan bahwa penggunaan media film efektif untuk meningkatkan sikap empati siswa kelas VII SMP.

Peneliti menggunakan media film karena mampu membantu dan memfasilitasi konseli agar mampu memenuhi tugas-tugas perkembangannya yang meliputi aspek belajar, pribadi, sosial dan karier. Menurut Jencius (2011) pada saat menonton film, individu akan dibawa pada kondisi emosional di film tersebut. Hal ini memungkinkan siswa untuk dapat merasakan apa yang ada di dalam film dan jika dikaitkan dengan penelitian ini, siswa belajar meningkatkan sikap empati mereka. Film yang ditayangkan harus mempunyai tokoh yang mempunyai sikap empati yang tinggi sehingga tokoh tersebut mampu menginspirasi siswa agar mampu meniru dan mengaplikasikan ke dalam kehidupan sehari-hari. Ada lima film yang digunakan dalam penelitian ini, yakni film "Surat Kecil untuk Tuhan”, “Negeri 5 Menara”, “Ayah Mengapa Aku Berbeda”, “Sang Pemimpi”, dan "Denias”.

Dalam teori yang dijelaskan oleh Bandura (dalam Slavin, 2008) proses mengamati dan meniru perilaku dan sikap orang lain sebagai model merupakan tindakan belajar. Dalam melakukan pengamatan tersebut, terdapat aspek kognitif yang menjadi dasar timbulnya tingkah laku yang sesuai dengan apa yang telah diamati. Pada modeling ini, individu tidak sepenuhnya meniru dan mencontoh perilaku dari orang-orang tersebut, namun individu juga memperhatikan hal-hal apa saja yang baik semestinya untuk ditiru atau dicontoh dengan cara melihat bagaimana reinforcement atau punishment yang akan ditiru. Menurut Bandura (dalam Slavin, 2008) terdapat empat proses yang terlibat di dalam pembelajaran melalui pendekatan modeling, yaitu perhatian, pengingatan, reproduksi dan motivasi.

Pada saat melakukan treatment, ada beberapa tahapan yang harus dilakukan oleh peneliti, yakni penayangan film, refleksi dan diskusi. Pada saat penayangan film, siswa diberikan film-film yang di dalamnya mengandung nilai-nilai empati sehingga setelah melihat film, siswa diharapkan mampu meningkatkan sikap empatinya. Diperlukan keterampilan berkomunikasi dan mengelola kelas dari peneliti agar bisa mengkondisikan subjek penelitian agar mampu mengikuti seluruh kegiatan dengan serius dan sungguh-sungguh.Hal itu dikarenakan pada saat penayangan film, peneliti sedikit mengalami kendala karena lamanya durasi film membuat beberapa subjek penelitian mengalami kebosanan. Hal itu bisa dilihat dari hasil observasi pada setiap pertemuan. Misalnya saja subjek penelitian SAZ dan RA. Subjek penelitian SAZ pada pertemuan pertama, pada pertengahan film kedapatan melihat film sambil membaca novel. Subjek penelitian RA pada pertemuan pertama dan keempat kedapatan melihat film sambil memainkan HP.

Pada saat refleksi, siswa diminta mengisi lembar refleksi yang terdiri dari refleksi isi dan pengalaman. Selanjutnya hasil refleksi yang telah dikerjakan didiskusikan bersama-sama. Pada saat diskusi, siswa diberi kesempatan untuk saling bertukar pendapat seputar film yang telah mereka lihat. Selain itu, pada saat diskusi siswa juga mampu mencari atau membuat solusi jika mereka mengalami peristiwa seperti yang ada di dalam film. Pada tahap refleksi dan diskusi ini, hampir semua subjek penelitian aktif dalam mengutarakan pendapatnya. Hanya subjek penelitian RA yang kurang begitu aktif dalam tahap refleksi.

\section{SIMPULAN DAN SARAN}

\section{Simpulan}

Kesimpulan dari penelitian ini adalah ada perbedaan tingkat empati siswa kelas VII SMP sebelum dan sesudah diberikan treatment. Hal ini dibuktikan dari hasil analisis dengan menggunakan uji wilcoxon yang diperoleh nilai beda (z) sebesar -2,201 dan nilai signifikansinya (2-tailed) adalah 0,028. Nilai signifikansinya lebih kecil dari 0,05 (nilai asyimp.sig $<0,05$ ) menunjukkan bahwa $\mathrm{H}_{0}$ ditolak, sehingga dapat disimpulkan bahwa penggunaan media film efektif untuk meningkatkan sikap empati siswa kelas VII SMP. 


\section{Saran}

Saran diberikan pada konselor untuk: (1) memperhatikan ketersediaan waktu terlebih dahulu sebelum menggunakan media film dalam melakukan kegiatan bimbingan kelompok, (2) mengetahui tokoh, isi cerita dan pesan yang terkandung di dalam film yang akan ditayangkan dan dalam menggunakan media film, (3) memperhatikan proses pengeditan film. Saat pengeditan, isi atau pesan yang ada di dalam film tidak boleh ikut terpotong. Selain itu, durasi film juga sebaiknya disesuaikan dengan jam pelajaran BK di sekolah.

Saran untuk peneliti selanjutnya (1) dalam melaksanakan penelitian, sebaiknya menggunakan kelompok kontrol agar bisa diketahui perbedaan skor antara kelompok kontrol dengan kelompok eksperimen, (2) sebaiknya posttest diberikan pada setiap akhir pertemuan agar peningkatan dan perkembangan sikap empati siswa dapat diketahui pada setiap pertemuan.

\section{DAFTAR RUJUKAN}

Arikunto, Suharsimi. 2006. Metodologi Penelitian. Yogyakarta: Bina Aksara.

Arsyad, A. 2002. Media Pembelajaran. Jakarta: Raja Grafindo Persada.

Arsyad, A. 2011. Media Pembelajaran. Jakarta: PT Raja Grafindo Persada.

Byrne, Donn \& Baron, Robert A. 2003. Psikologi Sosial Edisi Kesepuluh Jilid 1. Sidoarjo: PT Erlangga Kartono, K. 2003. Kamus Psikologi. Bandung: Pionir Jaya.

Nursalim, M., \& Mustaji. 2010. Media Bimbingan dan Konseling. Surabaya: Unesa University Press

Pearce, S. S., Jencius \& Studervant. 2011. What Experts Say about Cinema Therapy, (online), (http:// www.cinematherapy.com), diakses25 Maret 2015.

Prayitno \& Amti, E. 2008. Dasar-Dasar Bimbingan Konseling. Jakarta: Rineka Cipta.

Sarwono, S.W. 2011. Psikologi Remaja. Jakarta: Raja Grafindo Persada.

Slavin, R.E. 2008. Psikologi Pendidikan Teori dan Praktik. Jakarta: PT Indeks.

Sugiyono. 2011. Metode Penelitian Kuantitatif, Kualitatif dan R\&D. Bandung:Alfabeta.

Taufik. 2012. Empati Pendekatan Psikologi Sosial. Jakarta: Raja Grafindo. Persada.

Universitas Negeri Malang. 2010. Pedoman Penulisan Karya.

Ilmiah.-Skripsi,Tesis, Desertasi, Artikel, Makalah, Tugas Akhir, Laporan Penelitian (edisi kelima).

Malang: Penerbit Universitas Negeri Malang. 